\title{
Assessment of Knowledge toward Scabies, its Transmission and Prevention among Syrian Refugees in North of Jordan
}

Khaled Seetan ( $\sim$ Khaled.seetan@gmail.com )

Yarmouk University

Yasser Rashdan

Yarmouk University

Adel Alsharei

Yarmouk University

Sharaf Al Bashir

Yarmouk University

Abdallah Almadani

Yarmouk University

Mousa Alqa'dan

Mutah University

Ashraf Ashraf Al Momani

Mutah University

Yousef Rubbai

Al-Hussein Bin Talal University

Hashem Al Samarah

Jordan University of science and technology

\section{Research Article}

Keywords: Scabies, knowledge, refugees, infestation, parasites, pruritus,

Posted Date: June 4th, 2021

DOl: https://doi.org/10.21203/rs.3.rs-570553/v1

License: (c) (i) This work is licensed under a Creative Commons Attribution 4.0 International License.

Read Full License 


\section{Abstract}

Background: Scabies is one of the prevalent dermatological conditions, accounting for a substantial proportion of skin diseases in developing countries. It represents a significant health challenge when an outbreak appears in homecare and refugee camps as it may lead to enormous morbidity and high treatment costs. Because scabies can be easily prevented through education, the purpose of this study was to assess the level of scabies knowledge among Syrian refugees in Jordan's northern region.

Methodology: This cross-sectional study was conducted among Syrian refugees who attend a primary health center in northern Jordan, Ramtha from March 2021 to April 2021. The targeted population was adult Syrian refugees, above the age of 18 . Two thousand participants were included in this study using simple random selection. The study questionnaire included questions about socio-demographic characteristics and knowledge questions such as: ever hearing about scabies, causes of scabies, signs and symptoms of scabies and its way of transmission. The data was analyzed using (SPSS) version 25.

Results: Females with a mean age of 37.9 years old comprised the majority of the participants. The majority of the participants was married and had intermediate levels of education. The level of knowledge about scabies was poor among the majority of the respondents $(N=1259) ; 321$ respondents had moderate knowledge, while only 650 had good knowledge. A statistically significant association was found between knowledge score and all demographic characteristics, including gender, marital status, income and educational level.

Conclusion: The general knowledge about Scabies among Syrian refugees is relatively low, with 1259 out of 2000 participants having a poor knowledge score. Health education for refugees is needed to improve their knowledge and help implement prevention programs.

\section{Introduction}

Scabies is a common skin parasitic infection caused by Sarcoptes scabiei var hominis; it is an endemic disease in tropical and subtropical regions worldwide. It affects more than 130 million individuals worldwide at any given moment. In the recent research, rates of scabies incidence range from 0.3 percent to 46 percent. In the developed world, outbreaks in health institutions and vulnerable communities contribute to the high economic cost of national health services. [1-3] However, in resource-poor tropical settings, the sheer burden of scabies infestation and complications imposes a high cost on healthcare systems. It was predicted in 2010 that scabies direct effects on the skin resulted in more than 1.5 million YLDS (years lived with disability), with the indirect impacts on renal and cardiovascular function being even more substantial [4]

The $0.4 \mathrm{~mm}$ mite makes burrows in the host epidermis to put their eggs. The disease manifestations are mainly due to the infestation by Sarcoptes mites and the host immune response against the mites, eggs and other byproducts of the parasite. The immune response leads to intense itching in response to just a few mites [5]. Scabies infestation is usually complicated by bacterial infection; staphylococci or 
streptococci are common, leading to the development of skin sores that can cause more severe consequences such as septicemia, heart disease and chronic kidney disease.[6-8]

Scabies is typically transmitted from person to person through physical contact. Transmission through families, particularly from mother to infant, is extremely common [9]. Scabies infection is most often a result of unhealthy behavior such as poor personal hygiene, exchanging clothes and sharing bedding or personal items. Numerous additional elements may contribute to Scabies transmissions, such as high population density, low socioeconomic status, poor environmental conditions and lack of knowledge about personal hygiene.[9]

Schools typically do not provide the level of contact required for transmission. Sexual interaction is frequently the method of transmission among young adults. But we should consider the fact that one single case of scabies introduced into a crowded community can result in an epidemic [10].

In typical conditions, mites can survive off a host for 24 to 36 hours [11]. Although uncommon, there are numerous documented cases of scabies being contracted by wearing or handling heavily contaminated clothing or sleeping in a bed that had previously been occupied by an infested individual. Transmission through clothing or linens is more likely with higher parasite burdens, as seen in crusted (Norwegian) Scabies $[12,13]$. Scabies mites, in general, cannot survive for more than two to three days away from human skin. Appropriate options for items used within several days before treatment (for example, clothing, linens, stuffed animals) include placing them in a plastic bag for at least three days, machine washing with hot water and then ironing or drying in a hot dryer, or dry cleaning [14]. Scabies often occur among communities with overcrowded living conditions, such as refugee camps, which facilitate the transmission of various contagious diseases, especially skin diseases [15]. Poverty with its typical consequences; inadequate living conditions, overcrowding, and a low level of education seem to be a significant driving force for maintaining a high incidence and prevalence of the disease [16].

Since the Syrian crisis in 2011, many refugees have been displaced to many countries, including Jordan, which has the second-highest share of Syrian refugees, 89 refugees per 1000 inhabitants. $80 \%$ of those refugees live below the poverty line, and around 51\% were children. Scabies represents a significant health challenge when an outbreak appears in homecare and refugee camps as it may lead to colossal morbidity and high treatment costs. Because scabies can be easily avoided through education, the purpose of this study was to assess the level of scabies knowledge among Syrian refugees in Jordan's northern region.[17]

\section{Methodology}

This cross-sectional study was conducted among adult Syrian refugees who attend a primary health care center in northern Jordan, Ramtha. The targeted population was adult Syrian refugees aged, 18 years of age and above, who agreed to participate; those who declined to participate in the study were excluded. Two thousand participants were included in this study using simple random selection. 
The study questionnaire included questions about socio-demographic characteristics of the participants, such as age, gender, level of education, and marital status. The rest of the questionnaire consists of knowledge questions such as: ever hearing about scabies, causes of scabies, signs and symptoms of scabies and its way of transmission. The data was collected in around four weeks using a structured datasheet. The data was entered into a datasheet, then into an excel document, and then analyzed using the statistical package for social science (SPSS) version 25. Written informed consent was obtained from each of the participants.

The level of knowledge was measured using a scoring system with one mark given for each correctly answered question as follows: Good: 10-14, moderate :7-10, poor : less than 7.

\section{Results}

Females with a mean age of 37.99 years old comprised the majority of the participants. Most of the participants were married and had intermediate levels of education. (Table 1) 
Table 1

Demographic characteristics of the Syrian refugees in northern Jordan $(n=2230)$.

\begin{tabular}{|lll|}
\hline & Frequency/ mean \pm SD & Percent \\
\hline Age & $37.99 \pm 13.2$ & \\
Gender & 1085 & 48.7 \\
Male & 1145 & 51.3 \\
Female & & \\
\hline Marital status & 543 & 24.3 \\
Single & 1638 & 73.5 \\
Married & 22 & 1 \\
Divorced & 27 & 1.2 \\
Widowed & & \\
\hline Income ( \$) & 730 & 32.7 \\
Less than 250 & 1164 & 52.2 \\
Between 250 and 500 & 336 & 15.1 \\
More than 500 & & 13.6 \\
\hline Educational level & 282 & 73.3 \\
Primary & 1634 & 0.9 \\
Intermediate & 19 & 13.2 \\
Secondary & 295 & \\
Bachelor & & \\
\hline
\end{tabular}

Although Only $2 \%$ of the participants had not ever heard of scabies (Fig. 1), the level of knowledge about scabies was poor (less than 7) among the majority of the respondents $(N=1259) ; 321$ had moderate knowledge (7-10) while only 650 had good knowledge (10-14) about scabies ( Fig. 2).

In general, $69.7 \%$ of the respondents agreed that a skin parasite causes scabies; however, the majority of the participants, $84.4 \%$, reported that scabies cause no itching. The level of knowledge about scabies transmission mode was poor as nearly one third of the respondents believed that scabies could be transmitted by direct body contact, while about half of the respondents stated that they do not know if scabies can be transmitted by blood and droplets or not, moreover, $47 \%$ agreed that scabies could be transmitted through sharing of clothes and towels. 
About $48.3 \%$ of the participants agreed that scabies is not self-limiting and that infected patients should be isolated. Only one third of the participants agreed that taking care of personal hygiene helps prevent Scabies transmission. The majority believed that treatment should start immediately following the diagnosis and all family members of the infected patients need to be examined and followed. Nearly more than half of the participants agreed that there is no need for environmental disinfection by pesticides following the diagnosis. The majority of participants agreed that scabies can be very harmful and severe; they also did not know if scabies only affects older people or not, and they agreed that daily body washing helps clear scabies.(Table 2) 
Table 2

Syrian refugees' knowledge about Scabies, Northern Jordan $(n=2230)$.

\begin{tabular}{|c|c|c|}
\hline & Count. & $\%$ \\
\hline Scabies is caused by a skin parasite & 1555 & 69.7 \\
\hline Yes* & 355 & 15.9 \\
\hline No & 320 & 14.3 \\
\hline \multicolumn{3}{|l|}{ I do not know } \\
\hline Scabies causes no itching. & 1883 & 84.4 \\
\hline Yes & 337 & 15.1 \\
\hline No* & 10 & 0.4 \\
\hline \multicolumn{3}{|l|}{ I don't know } \\
\hline Direct body contact can transmit scabies. & 845 & 37.9 \\
\hline Yes* & 1025 & 46 \\
\hline No & 360 & 16.1 \\
\hline \multicolumn{3}{|l|}{ I don't know } \\
\hline Scabies can be transmitted through blood and droplets & 57 & 2.6 \\
\hline Yes & 1048 & 47 \\
\hline No* & 1125 & 50.4 \\
\hline \multicolumn{3}{|l|}{ I don't know } \\
\hline Scabies is not transmitted through sharing clothes and towel of an infested patient. & 271 & 12.2 \\
\hline Yes & 1049 & 47 \\
\hline No* & 910 & 40.8 \\
\hline \multicolumn{3}{|l|}{ I don't know } \\
\hline There is no need to isolate infested patients & 751 & 33.7 \\
\hline Yes & 921 & 41.3 \\
\hline No* & 558 & 25 \\
\hline I don't know & & \\
\hline
\end{tabular}




\begin{tabular}{|c|c|c|}
\hline & Count. & $\%$ \\
\hline There is no need to isolate infested patients as it is self-limiting & 701 & 31.4 \\
\hline Yes & 1076 & 48.3 \\
\hline $\mathrm{No}^{*}$ & 453 & 20.3 \\
\hline \multicolumn{3}{|l|}{ I don't know } \\
\hline Taking care of personal hygiene helps to prevent scabies transmission & 709 & 31.8 \\
\hline Yes* & 1329 & 59.6 \\
\hline No & 192 & 8.6 \\
\hline \multicolumn{3}{|l|}{ I don't know } \\
\hline All family members of infested patients need to be examined and followed. & 1637 & 73.4 \\
\hline Yes* & 142 & 6.4 \\
\hline No & 451 & 20.2 \\
\hline \multicolumn{3}{|l|}{ I don't know } \\
\hline Treatment should start immediately following diagnosis. & 1531 & 68.7 \\
\hline Yes* & 378 & 17 \\
\hline No & 321 & 14.4 \\
\hline \multicolumn{3}{|l|}{ I don't know } \\
\hline Environmental disinfestation using pesticide spray is essential following diagnosis. & 530 & 23.8 \\
\hline Yes & 1287 & 57.7 \\
\hline $\mathrm{No}^{*}$ & 413 & 18.5 \\
\hline \multicolumn{3}{|l|}{ I don't know } \\
\hline Scabies affects only old age people. & 428 & 19.2 \\
\hline Yes & 650 & 29.1 \\
\hline $\mathrm{No}^{*}$ & 1152 & 51.7 \\
\hline \multicolumn{3}{|l|}{ I don't know } \\
\hline Scabies can be very harmful and serious & 1508 & 67.6 \\
\hline Yes & 452 & 20.3 \\
\hline No* & 270 & 21.1 \\
\hline I don't know & & \\
\hline
\end{tabular}




\begin{tabular}{|lll|}
\hline & Count. & $\%$ \\
\hline Daily body wash helps clear scabies. & 1656 & 74.3 \\
Yes & 265 & 11.9 \\
No* & 309 & 13.9 \\
I don't know & & \\
\hline
\end{tabular}

The study showed a strong negative correlation between the age of the participants and Scabies knowledge score.(Table 3).There was also a statistically significant association between knowledge score and all demographic characteristics, including gender, marital status, income and educational level (Table 4).

Table 3

Correlation between age and scabies knowledge scores among Syrian refugees in Northern Jordan $(n=2230)$.

\begin{tabular}{|lll|}
\hline & & Knowledge score \\
\hline age & Pearson Correlation & $-.811^{\star *}$ \\
\cline { 2 - 3 } & p-value & .000 \\
$\mathrm{~N}$ & 2230 \\
\hline
\end{tabular}


Table 4

Comparison of knowledge scores across

demographics of the Syrian refugees in Northern Jordan $(n=2230)$

\begin{tabular}{|lll|}
\hline & Mean \pm SD & p-value \\
\hline Gender & $7.9 \pm 3$ & $<0.001$ \\
Male & $4.1 \pm 2$ & \\
Female & & \\
\hline Marital status & $8.3 \pm 1$ & $<0.001$ \\
Single & $5.3 \pm 3.3$ & \\
Married & $3.6 \pm 0.5$ & \\
Divorced & $2.3 \pm 0.5$ & \\
Widowed & & \\
Income & $3.8 \pm 2.1$ & $<0.001$ \\
Less than 250 & $6.3 \pm 3.1$ & \\
Between 250 and 500 & $9.6 \pm 2$ & \\
More than 500 & & \\
\hline Educational level & $2.3 \pm 0.5$ & $<0.001$ \\
Primary & $5.7 \pm 3$ & \\
Intermediate & 11 & \\
Secondary & $10.5 \pm 0.5$ & \\
Bachelor & & \\
\hline
\end{tabular}

The difference between the marital status groups was significant except for the difference between widowed and divorced (Table 5). The difference in the knowledge score is significantly different among the three different income groups (Table 6). A significant difference was found between all the different education levels and the knowledge score, except for the difference between secondary and bachelor's degrees. (Table 7). 
Table 5

Post-hoc test for mean differences of knowledge scores among marital status groups of the Syrian refugees in Northern Jordan $(n=2230)$.

\section{Tukey HSD}

\begin{tabular}{|c|c|c|c|c|c|c|}
\hline \multirow[t]{2}{*}{ (I) income } & \multirow[t]{2}{*}{ (J) income } & \multirow{2}{*}{$\begin{array}{l}\text { Mean Difference } \\
(I-J)\end{array}$} & \multirow{2}{*}{$\begin{array}{l}\text { Std. } \\
\text { Error }\end{array}$} & \multirow[t]{2}{*}{ Sig. } & \multicolumn{2}{|c|}{$95 \%$ Confidence Interval } \\
\hline & & & & & $\begin{array}{l}\text { Lower } \\
\text { Bound }\end{array}$ & $\begin{array}{l}\text { Upper } \\
\text { Bound }\end{array}$ \\
\hline \multirow[t]{2}{*}{ Less than 250} & $\begin{array}{l}\text { Between 250- } \\
500\end{array}$ & $-2.51597^{\star}$ & .12731 & .000 & -2.8145 & -2.2174 \\
\hline & More than 500 & $-5.85887^{\star}$ & .17777 & .000 & -6.2758 & -5.4419 \\
\hline \multirow{2}{*}{$\begin{array}{l}\text { Between 250- } \\
500\end{array}$} & Less than 250 & $2.51597^{*}$ & .12731 & .000 & 2.2174 & 2.8145 \\
\hline & More than 500 & $-3.34291^{\star}$ & .16700 & .000 & -3.7346 & -2.9512 \\
\hline \multirow[t]{2}{*}{ More than 500} & Less than 250 & $5.85887^{\star}$ & .17777 & .000 & 5.4419 & 6.2758 \\
\hline & $\begin{array}{l}\text { Between 250- } \\
500\end{array}$ & $3.34291^{*}$ & .16700 & .000 & 2.9512 & 3.7346 \\
\hline
\end{tabular}

*. The mean difference is significant at the 0.05 level. 
Table 6

Post-hoc test for mean differences of knowledge scores among income groups in the Syrian refugees in Northern Jordan $(n=2230)$.

\section{Tukey HSD}

\begin{tabular}{|c|c|c|c|c|c|c|}
\hline \multirow{2}{*}{$\begin{array}{l}\text { (I) marital } \\
\text { status }\end{array}$} & \multirow{2}{*}{$\begin{array}{l}\text { (J) marital } \\
\text { status }\end{array}$} & \multirow{2}{*}{$\begin{array}{l}\text { Mean Difference } \\
(I-J)\end{array}$} & \multirow{2}{*}{$\begin{array}{l}\text { Std. } \\
\text { Error }\end{array}$} & \multirow[t]{2}{*}{ Sig. } & \multicolumn{2}{|c|}{$95 \%$ Confidence Interval } \\
\hline & & & & & $\begin{array}{l}\text { Lower } \\
\text { Bound }\end{array}$ & $\begin{array}{l}\text { Upper } \\
\text { Bound }\end{array}$ \\
\hline \multirow[t]{3}{*}{ Single } & Married & $3.09124^{*}$ & .14822 & .000 & 2.7102 & 3.4723 \\
\hline & Divorced & $4.74669^{\star}$ & .65096 & .000 & 3.0731 & 6.4203 \\
\hline & Widowed & $6.08676^{*}$ & .59019 & .000 & 4.5694 & 7.6041 \\
\hline \multirow[t]{3}{*}{ Married } & Single & $-3.09124^{*}$ & .14822 & .000 & -3.4723 & -2.7102 \\
\hline & Divorced & $1.65546^{*}$ & .64243 & .049 & .0038 & 3.3071 \\
\hline & Widowed & $2.99552^{*}$ & .58077 & .000 & 1.5024 & 4.4887 \\
\hline \multirow[t]{3}{*}{ Divorced } & Single & $-4.74669^{*}$ & .65096 & .000 & -6.4203 & -3.0731 \\
\hline & Married & $-1.65546^{*}$ & .64243 & .049 & -3.3071 & -.0038 \\
\hline & Widowed & 1.34007 & .85969 & .403 & -.8702 & 3.5503 \\
\hline \multirow[t]{3}{*}{ Widowed } & Single & $-6.08676^{*}$ & .59019 & .000 & -7.6041 & -4.5694 \\
\hline & Married & $-2.99552^{*}$ & .58077 & .000 & -4.4887 & -1.5024 \\
\hline & Divorced & -1.34007 & .85969 & .403 & -3.5503 & .8702 \\
\hline
\end{tabular}


Table 7

Post-hoc test for mean differences of knowledge scores among educational level groups of the Syrian refugees in Northern Jordan $(n=2230)$.

\section{Tukey HSD}

\begin{tabular}{|c|c|c|c|c|c|c|}
\hline \multirow[t]{2}{*}{$\begin{array}{l}\text { (I) educational } \\
\text { level }\end{array}$} & \multirow[t]{2}{*}{$\begin{array}{l}\text { (J) educational } \\
\text { level }\end{array}$} & \multirow[t]{2}{*}{$\begin{array}{l}\text { Mean Difference } \\
(I-J)\end{array}$} & \multirow[t]{2}{*}{$\begin{array}{l}\text { Std. } \\
\text { Error }\end{array}$} & \multirow[t]{2}{*}{ Sig. } & \multicolumn{2}{|c|}{$\begin{array}{l}95 \% \text { Confidence } \\
\text { Interval }\end{array}$} \\
\hline & & & & & $\begin{array}{l}\text { Lower } \\
\text { Bound }\end{array}$ & $\begin{array}{l}\text { Upper } \\
\text { Bound }\end{array}$ \\
\hline \multirow[t]{3}{*}{ Primary } & Intermediate & $-3.36256^{*}$ & .16293 & .000 & -3.7814 & -2.9437 \\
\hline & Secondary & $-8.61348^{*}$ & .59887 & .000 & -10.1532 & -7.0738 \\
\hline & Bachelor & $-8.07449^{*}$ & .21043 & .000 & -8.6155 & -7.5335 \\
\hline \multirow[t]{3}{*}{ Intermediate } & Primary & $3.36256^{*}$ & .16293 & .000 & 2.9437 & 3.7814 \\
\hline & Secondary & $-5.25092^{*}$ & .58303 & .000 & -6.7499 & -3.7520 \\
\hline & Bachelor & $-4.71193^{*}$ & .15984 & .000 & -5.1229 & -4.3010 \\
\hline \multirow[t]{3}{*}{ Secondary } & Primary & $8.61348^{*}$ & .59887 & .000 & 7.0738 & 10.1532 \\
\hline & Intermediate & $5.25092^{*}$ & .58303 & .000 & 3.7520 & 6.7499 \\
\hline & Bachelor & .53898 & .59804 & .804 & -.9986 & 2.0765 \\
\hline \multirow[t]{3}{*}{ Bachelor } & Primary & $8.07449^{\star}$ & .21043 & .000 & 7.5335 & 8.6155 \\
\hline & Intermediate & $4.71193^{\star}$ & .15984 & .000 & 4.3010 & 5.1229 \\
\hline & Secondary & -.53898 & .59804 & .804 & -2.0765 & .9986 \\
\hline
\end{tabular}

\section{Discussion}

This analytical cross-sectional study was conducted to evaluate the knowledge of the Syrian refugees in the northern area of Jordan about Scabies, its transmission and prevention. It was investigating the knowledge about the case of the disease, its signs and symptoms, ways of transmission, whether it is self-limiting or not, the importance of early treatment and the seriousness of the disease. The study also investigates the association between the demographic and the knowledge score.

This study finds an overall poor level of knowledge about scabies among the study participants, In contrast to previous studies done in Saudi Arabia 2018 [18], and Indonesia where a good level of 
knowledge was found among the majority of the participants [4].

While these findings are comparable to the findings of another study done among medical students living in an endemic region, overall unsatisfactory knowledge of scabies has been reported [19].

In general, $69.7 \%$ of the respondents agreed that a skin parasite causes scabies; however, the majority of

the participants, $84.4 \%$, showed agreement with the statement that scabies cause no itching. Considering the fact that Pruritus, the result of a hypersensitive reaction to components of the saliva, eggs, and other material of the mites, is the main symptoms of the disease, it typically worsens at night and can prevent patients from sleeping well [20].

These study findings contrast with what has been found in another previous study, where $93.3 \%$ of the participants knew that scratching is a prominent symptom of scabies [21]. Only $31.8 \%$ of the study participants agreed that taking care of personal hygiene helps prevent Scabies transmission. In fact, the spread of classic scabies without direct person-to-person contact is rare. However, the recovery of mites from chairs and beds in patients' homes with scabies supports the role of personal hygiene and other environmental measures [22]. Even though data is lacking to confirm the efficacy of some measures in reducing transmission, ideally, Clothing and bedding should be washed at $60^{\circ} \mathrm{C}$ and dried the day after the first treatment [23].

The majority agrees that treatment should begin as soon as the diagnosis is made; these findings are consistent with those found in a previous study conducted in Guinea-Bissau, where participants recognized the importance of early treatment but were unaware that personal hygiene is essential for Scabies prevention and recurrence [24].

In order to have reasonable control over Scabies infection, treatment of affected individuals, as well as their contacts, is of vast importance [20]. Prescriptions should be provided for all household members and any sexual contacts, even if they are asymptomatic [12].

Treatment of close relatives was considered as not necessary by a previous study participants, while in this study, the majority agreed that all family members of the infected patients needed to be examined and followed [24].

A statistically significant association was found between the knowledge score and all demographic characteristics, including age, gender, marital status, income, and educational level. This may help explain the difference in the knowledge found between this study and the previous studies [4][18][21][24]. Furthermore, it also goes with a previous study where the results suggest a statistically significant association between marital status and level of knowledge about scabies [19].

\section{Conclusion}

The general knowledge about Scabies among Syrian refugees is relatively low, with 1259 out of 2000 participants having a poor knowledge score. Health education for refugees is needed to improve their 
knowledge and help implement prevention programs.

\section{Declarations}

\section{Ethics approval and consent to participate:}

Ethics approval and consent to participate and research protocols and methods have been has been approved by the IRB committee at King Abdullah University Hospital number (2712-13-1).All methods were performed in accordance with the relevant IRB committee guidelines and regulations. The principles of the World Medical Association and the Declaration of Helsinki were applied in this study. Written informed consent was obtained from all participants in this study. All participants were informed that their comments would be kept anonymous and that their quotations would be included in the paper.

\section{Consent for publication}

Not applicable

\section{Availability of data and materials}

The datasets used and/or analysed during the current study available from the corresponding author on reasonable request.

\section{Competing interests:}

The authors declare that there are no competing interests.

\section{Funding}

There is no funding source to report for this research

\section{Authors' contributions}

Seetan ,Rashdan , AlSharei and Rubbai contributed to the conception, design, acquisition of data, analysis, interpretation of data, and drafting of the manuscript. Seetan, Rashdan , AlSharei, Rubbai , ALBashir , Almadani, Alqa'dan, Almomani and Alsamarah made substantial contributions to the design of the study, data analysis and interpretation, and drafting and revising it critically for important intellectual content. All authors approved the final manuscript and agreed to be accountable for all aspects of the work.

\section{Acknowledgments}

The authors would like to pass their thanks to the cooperative staff at the primary health center where the study was conducted

\section{Authors' information}


Department of clinical Sciences, Faculty of Medicine, Yarmouk University, Irbid, Jordan : Khaled Seetan, Yasser Rashdan , Adel AlSharei, Sharaf ALBashir , Abdallah Almadani,

Princess Aisha Bint Al-Hussein College of Nursing and Health Sciences, Al-Hussein Bin Talal University, Maan, Jordan:

Yousef Rubbai

Faculty of Medicine ,Mutah University , Alkarak, Jordan :

Mousa Alqa'dan, Ashraf Almomani

Faculty of Medicine, Jordan University of Science and Technology:

Hashem al samarah

\section{References}

1. Walton SF, McKinnon M, Pizzutto S, Dougall A, Williams E, Currie BJ. Acaricidal activity of Melaleuca alternifolia (tea tree) oil: in vitro sensitivity of sarcoptes scabiei var hominis to terpinen-4-ol. Arch Dermatol. 2004;140(5):563-566. doi:10.1001/archderm.140.5.563

2. Hicks MI, Elston DM. Scabies. Dermatol Ther. 2009;22(4):279-292. doi:10.1111/j.15298019.2009.01243.x

3. Engelman D, Kiang K, Chosidow O, et al. Toward the global control of human scabies: introducing the International Alliance for the Control of Scabies. PLoS Negl Trop Dis. 2013;7(8):e2167. Published 2013 Aug 8. doi:10.1371/journal.pntd.0002167

4. -Binti M, Silvita F, Yunita D, A Study on Knowledge, Attitude and Practice in Preventing Transmission of Scabies in Pesantren Darul Fatwa, Jatinangor.Althea Medical Journal.2015, pp. 131-137.

5. - Currie BJ, Carapetis JR. Skin infections and infestations in Aboriginal communities in northern Australia. Australas J Dermatol. 2000;41(3):139-145. doi:10.1046/j.1440-0960.2000.00417.x

6. - Rajajee S. Post-streptococcal acute glomerulonephritis: a clinical, bacteriological and serological study. Indian J Pediatr. 1990;57(6):775-780. doi:10.1007/BF02722275

7. -Wong LC, Amega B, Connors $C$, et al. Outcome of an interventional program for scabies in an Indigenous community. Med J Aust. 2001;175(7):367-370. doi:10.5694/j.1326-5377.2001.tb143620.x

8. - Earle DP, Potter EV, Poon-King T, Finklea JF, Sharrett AR, Ortiz J. Streptococcal skin infections and epidemic acute nephritis in Trinidad. Trans Am Clin Climatol Assoc. 1970;81:184-195. 
9. - Walton SF, Currie BJ. Problems in diagnosing scabies, a global disease in human and animal populations. Clin Microbiol Rev. 2007;20(2):268-279. doi:10.1128/CMR.00042-06

10. -Ogunbiyi AO, Owoaje E, Ndahi A. Prevalence of skin disorders in school children in Ibadan, Nigeria. Pediatr Dermatol. 2005;22(1):6-10. doi:10.1111/j.1525-1470.2005.22101.x

11. -Cohen PR. Scabies masquerading as bullous pemphigoid: scabies surrepticius. Clin Cosmet Investig Dermatol. 2017;10:317-324. Published 2017 Aug 23. doi:10.2147/CCID.S145494

12. - Chosidow O. Clinical practices. Scabies. N Engl J Med. 2006;354(16):1718-1727. doi:10.1056/NEJMcp052784

13. - Dawoodzada U. Knowledge, attitude and practices on scabies among religious school (MADRASA ) hostel students of Helmand province Afghanistan. Int. J. of Adv. Res.2017, 5 (Jul):1506-1514.

15. - Banerji A; Canadian Paediatric Society, First Nations, Inuit and Métis Health Committee. Scabies. Paediatr Child Health. 2015;20(7):395-402. doi:10.1093/pch/20.7.395

16. - Hegab DS, Kato AM, Kabbash IA, Dabish GM. Scabies among primary schoolchildren in Egypt: sociomedical environmental study in Kafr El-Sheikh administrative area. Clin Cosmet Investig Dermatol. 2015;8:105-111. Published 2015 Feb 24. doi:10.2147/CCID.S78287

17. -UNHCR Jordan Factsheet - February 2018. Available online: https://reliefweb.int/report/jordan/unhcrjordan-factsheet-february-2018. Accessed April 2021.

18. - Abdullah Ayidh Alotaibi, Rasheed Khalid Baradah, Ahmed Abdulrhman Aldahash, Khalid Ayidh Alotaibi, Yasser Suliman Aleliwi. KNOWLEDGE AND ATTITUDE OF SCABIES AMONG GENERAL POPULATION IN MAJMAAH CITY, SAUDI ARABIA, 2018. INDO AMERICAN JOURNAL OF PHARMACEUTICAL SCIENCES, 06(01), 2218-2229. http://doi.org/10.5281/zenodo.2551676

19. -Halima Mwuese Sule, Zuwaira I. Hassan, Mark D. Gyang, Kenneth Yakuba. Knowledge of Scabies Among a Cohort of Medical Students. Open Science Journal of Clinical Medicine. 2015.Vol. 3, No. 5, pp. 177-181.

20. -Heukelbach J, Feldmeier H. Scabies. Lancet. 2006;367(9524):1767-1774. doi:10.1016/S01406736(06)68772-2

21. - Akbar, N., Hanif, A., Gilani, M. A. gilani, \& Yasmin, S. Assessing the Knowledge of Scabies Among the Women of a Rural Community at Lahore. International Journal of Social Sciences and Management,2020. 7(1), 30-37. https://doi.org/10.3126/ijssm.v7i1.27407

22. - Mnati SF, Habeeb M A, Mohammed AM. Influence of weather factors on sarcopte scabiei in Southern Iraq/Basra environs. Eurasia J Biosci,2020. 14: 2215-2219 
23. - Elston DM. Controversies concerning the treatment of lice and scabies. J Am Acad Dermatol. 2002;46(5):794-796. doi:10.1067/mjd.2002.121027

24. - Lopes MJ, da Silva ET, Ca J, et al. Perceptions, attitudes and practices towards scabies in communities on the Bijagós Islands, Guinea-Bissau. Trans R Soc Trop Med Hyg. 2020;114(1):49-56. doi:10.1093/trstmh/trz102

\section{Figures}

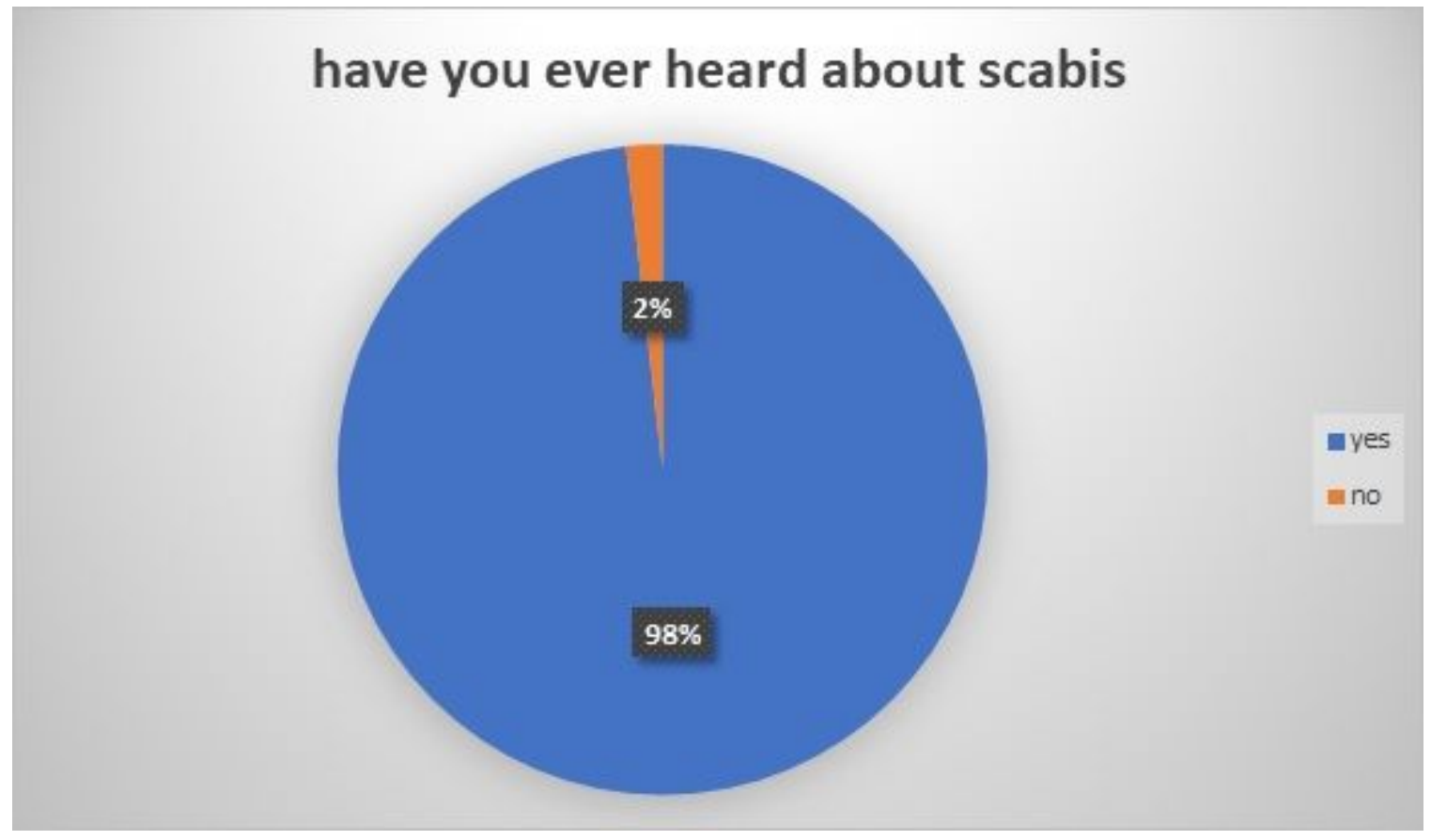

\section{Figure 1}

Proportion of participants heard about Scabies among Syrian refugees in northern Jordan $(n=2230)$. 


\section{knowledge}

anowledge

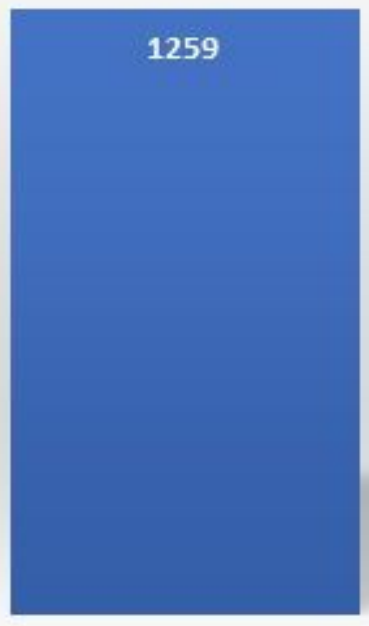

poor $(<7)$

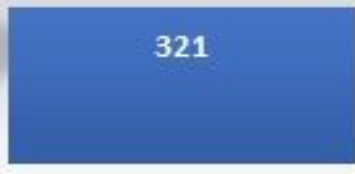

moderate $(7-10)$

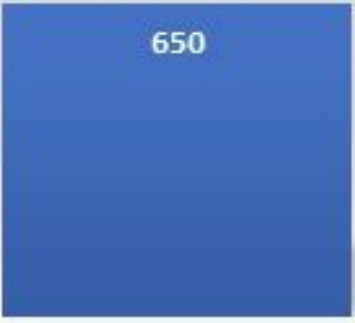

$\operatorname{good}(10-14)$

\section{Figure 2}

Illustration of Syrian refugees' knowledge about Scabies, northern Jordan ( $\mathrm{n}=2000)$ 